\title{
Package Tour Contracts in Times of COVID-19
}

\author{
Ömer Ali Girgin* ${ }^{*}$, Sebastian Löw* ${ }^{* *}$
}

\begin{abstract}
This comparative study deals with the question of whether travelers can terminate an already booked package tour free of charge after the outbreak of COVID-19 ("coronavirus") in EU law and Turkish law. It first provides preliminary information about the regulations related to package tour contracts. It explains afterwards, which package travelers have the right of termination and compares the conditions and legal consequences of termination of the contract, under the perspective of EU and Turkish laws. In this context, the terms such as unavoidable and extraordinary circumstances, force majeure, the situation that cannot be foreseen and prevented and the reason that not caused by consumer are examined in respect of the COVID-19 pandemic. Different results of the cancellation of the package tour or termination of contract are analyzed. Also a recent amendment in the directive about the package tour contracts in the Turkish law is criticized.
\end{abstract}

\section{Keywords}

Covid-19 pandemic, Package tour, Termination, Refund, Unavoidable and extraordinary circumstances

\section{COVID-19 Döneminde Paket Tur Sözleşmeleri}

\section{Öz}

Çalışma, halihazırda satın alınmış paket turların, COVID-19 salgını ("koronavirüs") ortaya çıktıktan sonra ücret kesintisi olmadan iade edilebilip edilemeyeceğini araştırmaktadır. Eserde öncelikle paket tur sözleşmeleri hakkındaki kanuni düzenlemeler hakkında ön bilgiler aktarılmıştır. Ardından, salgın sebebiyle hangi paket tur yolcularının sözleşmeyi sona erdirebileceği açıklanmış; sona erdirmenin şartları ve sona ermenin yasal sonuçları AB Hukuku ve Türk hukuku bakımından karşılaştırmalı olarak incelenmiştir. Bu çerçevede, kaçınılmaz ve olağanüstü şartlar, mücbir sebep, öngörülemeyen ve engellenemeyen durum, tüketiciden kaynaklanmayan sebepler gibi terimler COVID-19 pandemisi açısından incelenmiştir. Turun başlangıcından önce ve sonra turun iptali veya sözleşmenin sona erdirilmesi hallerinde ortaya çıkan farklı neticeler analiz edilmiştir. Ayrıca Türk hukukunda konuyla ilgili yakın tarihte yapılan yönetmelik değişikliği eleştirilmiştir.

\section{Anahtar Kelimeler}

Covid-19 pandemisi, Paket tur, Sözleşmenin sona erdirilmesi, Para iadesi, Kaçınılmaz ve olağanüstü haller

* Corresponding author: Ömer Ali Girgin (Ress. Asst), Anadolu University Faculty of Law, Civil Law, Eskişehir, Turkey. E-mail: omeraligirgin@anadolu.edu.tr ORCID: 0000-0001-7469-9174

** Sebastian Löw (Ress. Asst), University of Innsbruck, Faculty of Law, Corporate Law, Innsbruck, Austria. E-mail: sebastian.loew@uibk. ac.at ORCID: 0000-0001-7426-7531

To cite this article: Girgin OA, Low S, “Package Tour Contracts in Times of COVID-19" (2020) 78(2) İstanbul Hukuk Mecmuası 563. https://doi.org/10.26650/mecmua.2020.78.2.0011 


\section{Introduction}

A package tour can be defined simply as a vacation at a fixed price in which the travel agency plans for the travel, accommodation and sometimes food for the travelers. As a pandemic, effects of COVID-19 ("coronavirus") are seen worldwide. Travel bans were one of the first precautions taken by the governments ${ }^{1}$. In this context, flights have been stopped, customs have been closed and any kind of tourism mobility both domestically and internationally, has been prohibited. For this reason, a great number of people ${ }^{2}$ who booked and paid for package tours are struggling to get refund. This article deals with the question of whether travelers can terminate an already booked package tour free of charge after the outbreak of COVID-19. It explains and compares the conditions of the termination and which package travelers have the right of termination under the perspective of EU and Turkish laws.

\section{Termination under the perspective of EU law}

Package tourism in Europe is determined by the Package Travel Directive (Directive 2015/2302), which came into force on 1 July 2018. The directive is based on the principle of full harmonization (Directive 2015/2302 art 4) and is therefore fully and identically applicable in all member states of the EU Union (EU). ${ }^{3}$ Although the member states have transformed the Directive into their national law, the following paper is directly based on the Directive, as the legal situation is uniform and should therefore be explained in abstract terms for the entire EU. In order to concretize the paragraphs, German and Austrian case law will be consult. According to Directive 2015/2302 art 3 sub clause 2 a package tour is the combination of at least two different types of travel services for the purpose of the same trip. If the traveler has only booked individual services or linked travel arrangements (Directive 2015/2302 art 3 sub clause 5) the Directive 2015/2303 does not apply in case of such a withdrawal.

No traveler is obliged to actually take part in his booked package tour, which is why Directive 2015/2302 art 12/1 provides that a traveler may terminate the package tour contract at any time and without giving reasons. If the travaler is exercising his termination right, he must pay appropriate compensation (the so-called "termination fee"). ${ }^{4}$ Nevertheless, Directive 2015/2302 art 12/2 contains an important exception to this: if unavoidable and extraordinary circumstances occurring at the place of destination or its immediate vicinity and significantly affecting the performance of the package tour, or which significantly affect the carriage of passengers to the

\footnotetext{
https://www.nytimes.com/article/coronavirus-travel-restrictions.html

2 For instance, 1.5 million Turkish people buy package tours to go abroad per year. See Uğur Ceylan and Ömer Zafer Güven, 'Yerli Turistlerin Satın Aldıkları Yurtdışı (Outgoing) Paket Turları Değerlendirmeleri Üzerine Bir Araştırma' (2017) 2 (2) Bilecik Şeyh Edebali Üniversitesi Sosyal Bilimler Enstitüsü Dergisi 515, 515.

3 Ecker, 'Das neue Pauschalreisegesetz' (2017/2018) JAP 238, 238; Führich, 'Das neue Pauschalreiserecht' (2017) NJW 2945, 2945.

4 Tonner, 'Auswirkungen von Krieg, Epidemie und Naturkatastrophe auf den Reisevertrag' (2003) NJW 2783, 2783.
} 
destination, the traveler can terminate the package tour contract without paying any termination fee. In the present case it is therefore decisive whether the outbreak of COVID-19 can constitute such an event.

\section{A. Unavoidable and Extraordinary Circumstances}

According to the definition of Directive 2015/2302 art 3/1 sub clause 12, unavoidable and extraordinary circumstances are deemed to exist, if a situation is beyond the control of the party who invokes such a situation and the consequences of the situation could not have been avoided even if all reasonable measures had been taken. Whether an event constitutes such circumstances must be determined in each individual case. ${ }^{5}$

In case of an epidemic outbreak, the existence of unavoidable, exceptional circumstances is indisputable, since the Directive's Preamble refers to the outbreak of a serious disease at the destination as an example of the existence of such an event. ${ }^{6}$ This must also apply to the COVID-19 pandemic, as its wider geographical spread is the only difference to an epidemic. ${ }^{7}$

\section{B. Occurrence at the Place of Destination or in Its Immediate Vicinity}

Directive 2015/2302 art 12/2 requires that the unavoidable and extraordinary circumstance occurs at the place of destination or its immediate vicinity. But the Directive does not define more precisely what is meant by immediate vicinity. Since the immediate vicinity was also assumed according to the former legal situation, the previous jurisdiction can be used. The outbreak of an epidemic in a town 250 $\mathrm{km}$ away should not give rise to such a right of termination, due to the territorial restriction. ${ }^{8}$ A problem in this context is that the wording of the law does not cover places which must necessarily be passed during the journey to and from the place of destination. If the concept of immediate vicinity is interpreted teleologically, the conclusion is that places which must necessarily be passed during the journey to and from the place of destination are in the immediate vicinity of the place of destination because of their contractual vicinity. This outcome would be in line with Directive's Preamble, according to which a right of termination should be granted if safe travel to the final destination is impossible. ${ }^{9}$ If the disease has therefore already broken out at the place of departure or intermediate landing, this also fulfils the condition of immediate proximity, since not only the physical proximity to the place of destination

\footnotetext{
Steinrötter, ‘§ 651 h’ para 22 in Junker, Beckmann and Rüßmann (eds), jurisPraxisKommentar-BGB (juris 2020).

Directive 2015/2302's Preamble Para 31.

Klafki, Risiko und Recht (Mohr Siebeck 2017) 163; Löw (n1) 1253.

AG Königstein RRa 1996, 32.

Directive 2015/2302's Preamble Para 31.
} 
can be decisive. In the case of the COVID-19 pandemic, which is already prevalent worldwide, the result is that the geographical criterion is fulfilled in any case.

\section{Significant affectation}

The essential element of Directive 2015/2302 art 12/2 is the existence of a significant affect on the performance of the package tour. The package tour is significantly affected if, it is impossible, from an objective point of view, to carry out the package tour safely, ie the purpose of the journey as a whole is in question. This condition must be fulfilled ex ante at the time of termination. ${ }^{10}$ In the event of an epidemic spreading, the significant affect could result from a risk to the traveler's physical health. In this context, only the personal safety is important, not the operability of the package. ${ }^{11}$ The existence of a health risk is indicated in particular by a travel warning issued by the national Ministry of Foreign Affairs. ${ }^{12}$ However, the lack of a travel warning does not necessarily mean that a significant affect must be denied. But if the Ministry of Foreign Affairs does not issue a travel warning, the burden of proof that such circumstances nevertheless prevail at the destination rests with the traveler. ${ }^{13}$ In this case, the traveler can, for example, rely on serious media coverage or probably also on a health warning from the WHO. ${ }^{14}$ In the current situation regarding COVID-19, there are plenty of travel warnings from the Ministries of Foreign Affairs from the EU member states, a warning from the World Health Organization and a large amount of serious media coverage. In times of COVID-19, the trip is significantly affected in any case, therefore the EU travelers can terminate the package travel contract wihtout paying any termination fee.

\section{Termination Date}

The most controversial issue in this context is the moment at which the traveler can declare the termination of the package travel contract. From an ex ante point of view, the circumstances must still exist at the time of the journey, therefore the traveler has to make a forecast decision, a hasty termination would be at his expense. ${ }^{15}$ The German Federal Court of Justice ${ }^{16}$ basically grants the traveler the right of termination as soon as there is a probability of at least $25 \%$ that the significant affectation still exists at the time of the journey. Although this decision referred to the risk of hurricane weather,

\footnotetext{
Führich, Basiswissen Reiserecht (4th edn, Vahlen 2018) para 123.

Tonner (n 4) 2784.

Führich, Basiswissen Reiserecht (n 10) para 123.

3 Führich, 'Rücktritt vom Pauschalreisevertrag vor Reisebeginn wegen Covid-19-Pandemie' (2020) NJW 2137, 2138; Löw, 'Rechtsfolgen bei Änderung des Pauschalreisevertrags' (2020) VbR 133, 137f.

14 Steinrötter (n 5) para 23; OGH 6 Ob 145/04y RdW 2004, 724.

15 Bergmann and Blankenburg, 'Unvermeidbare außergewöhnliche Umstände im Pauschalreise- und Luftverkehrsrecht' (2019) NJW 3678, 3679; Teichmann, ‘§ 651 j’ para 3 in Jauernig (ed) Bürgerliches Gesetzubuch (17th edn, CH Beck 2018).

16 BGH (n 2) 3700: This decision referred to the risk of hurricane weather.
} 
the barrier must be just as low for the risk of corona infection, as this can be lifethreatening for the traveler. ${ }^{17}$

In contrast, the Austrian Court of Justice has ruled that it is necessary to wait with the termination to evaluate the risk as long as traveler would still have enough time to change the booked destination. ${ }^{18}$ This decision concerned a termination due to several PKK attacks and the threat to attack also vacation facilities. Unfortunately this decision result contains considerable legal uncertainty, since the possibility of rebooking depends on the individual case. In case of COVID-19 pandemic, not only one destination but the whole world is affected. Therefore the right of termination does not depend on whether there is still time for rebooking. In conclusion this means, that in Austria the the right of termination arises later than in Germany, where the 25 percent barrier needs to be exceeded. ${ }^{19}$ In Germany, termination is possible approximately 4 weeks before the start of the trip, ${ }^{20}$ in Austria the limit of admissibility would probably be around 2 weeks before the start of the trip, although both termination rights result from the same legal basis.

According to this situation, the question arises whether a cancellation under Directive 2015/2302 art 12/2 is still possible if the traveller books his journey in the knowledge of the existing pandemic. The thought behind the termination right is that the traveler should no longer be bound to the contract if circumstances in the destination area have changed in such a dangerous way. If the traveler is booking after the circumstances have already changed, he is no longer in need of protection. ${ }^{21}$ Therefore, for travellers who have booked their journey after the outbreak of the COVID-19 pandemic in March there exists no right of termination free of charge, because general civil law cannot (any longer) be applied to the withdrawal from a package travel contract due to the fully harmonising effect of the Directive 2015/2303 (Art 4).

\section{E. Legal consequences}

If the traveler exercises his right of termination, the travel agency is obliged to refund the traveler all amounts already paid for the package without delay and in any event within 14 days (Directive 2015/2302 art 12/4).

Due to the exceptional situation caused by COVID-19, the German Federal Government asked the EU Commission to temporarily grant the travel agencies a right

\footnotetext{
17 Führich (n 15) 2138.

18 OGH 6 Ob 145/04y RdW 2004, 724; OGH 1 Ob 257/01b RdW 2002, 211.

19 Löw, 'Die Auswirkungen von Epidemien und Pandemien auf Pauschalreise- und Luftbeförderungsverträge' (2020) ZVR $156,158$.

20 Führich (n 15) 2139f.

${ }^{21}$ Führich, 'Terror, Angst und höhere Gewalt - Antworten des Reiserechts' (2003) RRa 50, 55.
} 
to refund the already paid amounts in vouchers, for the purpose of liquidity assurance. Nevertheless, the EU Commission rejected the proposal, because it would contradict Directive 2015/2302 art 12/4. ${ }^{22}$ In addition, in case of insolvency of the travel agency, which is threatened by the high repayments by COVID-19, payments of the traveler are secured due to the mandatory insurance system according to Directive 2015/2302 art 17, while vouchers would not be secured. ${ }^{23}$ The EU Commission therefore pointed out that vouchers as an alternative to refunds are only possible on a voluntary basis and would be only attractive for the traveler if they would be protected by the state in case of insolveny. ${ }^{24}$

Furthermore it should not be ignored, that also the travel agency may withdraw from the package travel contract free of charge until the start of the package tour due to unavoidable and extraordinary circumstances, which prevent them from carrying out the package tour (Directive 2015/2302 art 12/3b). With regard to COVID-19, the actual impossibility (e.g. if the airlines stop flight operations or airports are closed) and legal impossibility of carrying out the journey (e.g. due to the issuing of entry bans in the destination area) plays a major role. Therefore, as long as such circumstances exist, the travel agent can also withdraw from the package travel contract without being liable for damages. ${ }^{25}$

\section{Termination under the Perspective of Turkish Law}

\section{A. A Brief Look at the Regulations Related to Package Tours in Turkish Law}

Package tour contract in Turkish law is defined in Law on Consumer Protection No 6502 ("TKHK"), art 51/1 as follows: "Package tour contracts are the contracts which at least two of the following services are sold or pledged to be sold together at the allin price by package tour organizers or their agents and the service takes more than twenty-four hours or includes overnight stay: a) transportation b) accommodation c) other tourism services not dependent on transportation and accommodation services." Package tour contracts are considered as a matter of consumer law under the Turkish law. That is why the main regulation about package tour contracts finds its place with ten sub-articles in the Law on Consumer Protection. It can be argued that it is questionable whether the definition of the contract is consistent with the literature ${ }^{26}$

\footnotetext{
In detail: https://ec.europa.eu/info/sites/info/files/recommendation_vouchers_en.pdf

Keiler, 'COVID-19: Gutscheinlösung für Reisende' (2020) RdW 329, 329.

24 EU Commission, Recommendations 2020/648 of 13 May 2020 on vouchers offered to passengers and travelers as an alternative to reimbursement for cancelled package travel and transport services in the context of the COVID-19 pandemic (15).

25 Löw (n 1) 1254.

26 Pauline J Sheldon and James Mak, 'The demand for package tours: A mode choice model' (1987) 25 (3) Journal of travel research 13, 14.
} 
and the EU law ${ }^{27}$. The main reason behind this inconsistency is that the TKHK was enacted before the regulation of the European Union in 2015 and was based on the old directive no. 90/314 ${ }^{28}$. Unlike the Directive 90/314, Directive 2015/2302 is based on the product, that is, the package tour itself, rather than the seller/provider, in order to prevent any package tour contract left outside the scope ${ }^{29}$. According to the article, there are three criteria for a contract to be considered as "package tour contract". The contract must include at least two of the services of transportation, accommodation and other services; there must be an all-in price that covers all of the services and the service must last longer than twenty-four hours or it must include an overnight stay. Contracts that do not fit even one of those criteria, cannot be considered as a package tour contract; therefore Law No 6502 cannot be applied to them ${ }^{30}$. Another significant article states that people who participate in package tours within the scope of their commercial or professional activities, also considered as consumers ${ }^{31}$ (TKHK art 51/9). Rights and obligations of the parties such as agency's liability, the obligation of giving informative brochure and a copy of the contract to the consumer, right of termination and right of compensation are other matters that regulated in art $51^{32}$.

Another regulation about package tours in Turkish law is the Directive on Package Tour Contracts (Paket Tur Sözleşmeleri Yönetmeliği- PTSY) which is promulgated by the Turkey's Ministry of Trade based on the Law No 6502. In the PTSY, regulations that took place in the Law on Consumer Protection art 51 are elaborated. However, it can be observed that some regulations in PTSY cause ambiguity and incoordination between the law (TKHK) and the directive (PTSY) $)^{33}$.

\section{B. Rights of Package Tour Travelers During COVID-19}

\section{In General}

TKHK art 51 spares two sub-articles to non-performance and poor performance of the package tour contract. PTSY is more elaborated with five articles. When determining the rights of consumers in case of non-performance or poor performance,

27 Ebru Ceylan, 'Paket Tur Sözleşmesiyle İlgili 6502 Sayılı Yeni Tüketicinin Korunması Hakkında Kanun 'a Göre Getirilen Düzenlemeler' (2015) 1 (1) İstanbul Aydın Üniversitesi Hukuk Fakültesi Dergisi 71, 75. The regulation implied is Council Directive 90/314/EEC art. 2. However, Directive (EU) 2015/2302 of the EU Parliament and of the Council of 25 November 2015 on package travel and linked travel arrangements, amended Regulation (EC) No 2006/2004 and Directive 2011/83/ EU of the EU Parliament and of the Council and repealed Council Directive 90/314/EEC.

28 Ece Baş Süzel, Tatil Sözleşmeleri (On İki Levha 2019), 146.

29 Baş Süzel (n 30) 148.

30 Ceylan ( n 21) 75; Süleyman Savaş, 'Paket Tur Sözleşmeleri' (Master Thesis, Atatürk University Social Sciences Institute 2019) 52; Baş Süzel (n 30) 148.

31 Ceylan (n 21) 78.

32 For details on obligations of parties see: Gökçen Bilge Özdemir, 'Paket Tur Sözleşmesinde Taraflar ve Tarafların Borçları ve Hakları' (2011) (2) Sosyal Bilimler Dergisi 68; Ömer Öksüz, 'Tüketici Hukukunda Paket Tur Sözleşmeleri' (2006) (66) Türkiye Barolar Birliği Dergisi 331, 343 - 344 .

33 See 2.2.1. 
both regulations can be examined under a dual classification: Rights of consumers in the period before the tour starts and in the period after the tour starts.

According to TKHK, if one of the essential elements of the package tour contract is changed or the tour is canceled before the tour starts due to reasons not caused by the consumer, consumer may accept the change or an alternative tour offered by the package tour organizer ${ }^{34}$. Consumer also has the right of termination of the contract (TKHK art 51/6). In case of termination of the contract, the package tour organizer or its agency must refund all the price paid by the consumer without any deduction as soon as getting the termination notification ${ }^{35}$ (TKHK art 51/6). On the other side, consumers have two different rights in the period after the tour starts. The consumer has the right to demand a reduction in the price due to any deficiencies that arise during the performance of the contract ${ }^{36}$. If organizer does not fulfill an important obligation after the tour starts, consumer can terminate the contract (TKHK art $51 / 7)^{37}$. As is seen, TKHK regulates consumer rights in the package tour contracts in two periods by taking the starting date of the tour as a milestone.

However, PTSY handles the matter in a more complicated way than TKHK. Regulations in PTSY about the period before the tour starts, can be examined in four parts. These parts are the cancellation of the tour, termination of the contract by the consumer when there are 30 days or more to the tour, termination of the contract by the consumer due to specific reasons when there are less than 30 days to the tour and termination of the contract by the consumer without an excuse when there are less than 30 days to the tour ${ }^{38}$. Further examination on the topic is going to take place below.

In a closer look, it can be argued that some regulations clearly indicate inconsistencies between TKHK and PTSY. The inconsistencies are mostly derived from the inattentive usage of the terminology and ignoring the hierarchy of norms. To be specific, while TKHK only uses the term "dönme” (Rücktritt; termination ex tunc); PTSY uses both "fesih" (Kündigung; termination ex nunc) and "dönme" in different articles for the exact same type of contract. Whenas "fesih" is only valid for contracts of continuous performance and it is proactive ${ }^{39}$. On the other hand, if a contract of continuous performance is to be terminated before the performance starts, the type of the termination is "dönme" 40 . Because in this case, the contract

\footnotetext{
Gülşah Hamamcıŏlu, 'Paket Tur Sözleşmelerinde Tüketicinin Korunması' (2010) 68 (1-2) İstanbul Üniversitesi Hukuk Fakültesi Mecmuası 275, 298 - 299.

35 Savaş (n 22) 91.

36 Çağlar Özel, Tüketicinin Korunması Hukuku (Seçkin 2019) 268.

37 Öksüz (n 24) 347.

38 Sezer Çabri, Tüketicinin Korunması Hakkında Kanun Şerhi (Adalet 2016) 845.

39 Fikret Eren, Borçlar Hukuku Genel Hükümler (Yetkin 2014) 1001.

40 Eren (n 41) 1001.
} 
is terminated retroactively. There is no interest that needs to be protected in the termination of the contract effective for the future ${ }^{41}$. When it comes to package tour contracts, termination is "ex tunc". As a conclusion, the proper term should only be "dönme"42. Another example is about deductions. There is a right to terminate in PTSY which does not take place in the TKHK. And while this right is being used, as mentioned above, consumer has to suffer deductions like taxes, fees and thirdparty payments when terminating the contract, even if the reason of termination is force majeure. This regulation can be criticized in terms of the unfairness of bearing the risk by only one party. A regulation which spreads the burden fairly among the parties, e.g. refunding half of the expenses instead of none to the consumer, would be better.

It is fair to say the pandemic named COVID-19 can be considered as force majeure under the Turkish law ${ }^{43}$. Thus, consumer rights in case of force majeure in TKHK and PTSY can be applied to package tour contracts affected by COVID-19. Adopting the opposite idea and not considering the pandemic in question as a case of force majeure, does not change the conclusion. Because, regulations aforesaid include not only the term "force majeure"; but also other terms such as "reasons not caused by the consumer" and "a situation that consumer could not foresee and prevent despite showing maximum necessary attention".

\section{In Case the COVID-19 Occurs Before the Tour Starts}

The pandemic may have occurred before the tour starts. PTSY repeats the article of TKHK which entitles consumers to terminate the contract or accept the alternative tour offer, in case of cancellation of the tour due to reasons not caused by the consumer or change of essential elements of the contract ${ }^{44}$ (Directive art 10\&11). Thus, if the tour is canceled by the organizer due to COVID-19 precautions taken by the authorities including travel bans, since the pandemic is a situation that not caused by the consumer, consumer has two options. They can either accept the offer for an alternative tour or terminate the contract without any deduction ${ }^{45}$ (TKHK art 51/6; Directive art 11). In case of accepting to participate in an alternative tour (e.g. postponement to a later date), there are specific conditions that the offered tour has to fulfill. The price of the offered package tour must be equal to or higher than the price

\footnotetext{
41 Baş Süzel (n 30) 233.

42 Baş Süzel (n 30) 234

43 See Announcement from Turkey Ministry of Treasury and Finance, Date: 03.04.2020 No 80100189-105[13-1540]-E.42718; Announcement from Turkey Ministry of Trade General-Directorate of Export, Date: 23.03.2020 No 31429883-451.01; Announcement from Revenue Administration of Turkey, Date: 04.06.2020, Access on: https://gib.gov.tr/mucbir-sebep-halikapsamindaki-65-yas-ve-ustunde-olan-bazi-mukellefler-tarafindan-sokaga-cikma

44 Emin Türkyılmaz, 'Paket Tur Sözleşmeleri’ (Master Thesis, Kadir Has University Social Sciences Institute 2017) 74 - 75; Feyza Eren Sayın, 'Paket Tur Sözleşmesinde Tüketicinin Korunması' (Master Thesis, İstanbul University Social Sciences Institute 2013) 139; Çabri (n 30) 845.

45 Savaş (n 22) 91; Çabri (n 30) 845.
} 
of the canceled tour and consumers cannot be forced to pay any additional fee. If the price of the offered tour is lower than the price of the canceled tour, organizer has to refund the difference.

Other than the cancellation, consumers have the right to terminate the contract. In such a scenario, consequences of the termination depend on the date and reason of termination. It is stated that if there are at least 30 days to the tour, the consumer has the right to terminate the contract without giving anything as an excuse (Directive art $16 / 2$ ). Termination must be notified in written or via durable medium ${ }^{46}$. If the termination notification is sent at least thirty days before the start of the package tour, the price paid by the consumer must be refunded without any deduction, except for the expenses arising from the taxes, fees and similar legal obligations. In other words, consumer can terminate the contract if there are 30 or more days to the tour and get full refund only giving up the mandatory expenses. Consumer does not have to show a reason while terminating the contract ${ }^{47}$.

On the other hand, consumer can still terminate the contract if there are less than 30 days to the tour. According to PTSY, if termination notification is sent less than 30 days before the start of the package tour, a certain amount or rate of deduction can be made, provided that it is stated in the package tour contract (Directive art 16/3). However, if termination notification is sent less than thirty days before the start of the package tour due to force majeure or a situation that they could not foresee and prevent despite showing maximum necessary attention, the price paid by the participant must be refunded without any deduction; except for the unavoidable costs arising from taxes, fees and similar legal obligations and documented and nonreturnable payments which are made to third parties by the organizer ${ }^{48}$ (Directive art 16/4). As the regulation indicates, PTSY makes a distinction here. If the termination results from a force majeure or a situation that they could not foresee and prevent despite showing maximum necessary attention, consumers are entitled to get a full refund except for the mandatory expenses and irreversible, documented third-party payments. In other cases where consumer cannot show a reason that meets the definition given in PTSY while terminating the contract, the refund can be reduced in the certain amount or at

\footnotetext{
46 Yusuf Erdem Mirhanoğulları, ‘6502 Sayılı Tüketicinin Korunması Hakkında Kanuna Göre Paket Tur Sözleşmesinde Tüketicinin Korunması’ (Master Thesis, İstanbul Aydın University Social Sciences Institute 2019) 65.

47 Türky1lmaz (n 32) 102. Before the TKHK No 6502, it was controversial whether the participants could terminate the contract without showing a reason. The issue discussed here is whether the participant who terminates the contract without a valid reason will compensate to the package tour organizer. In this context, the participant is required to indemnify the damages of the package tour organizer that will arise due to the termination of the contract, except for the participant's inability to participate in the tour. See Oktay S, Gezi Sözleşmeleri (Beta 1997) 218. In the provision of 16/2, the expenses that the participant may have to compensate in case of termination of the contract are clearly stated. However, the failure of the package tour organizer to get the compensation for the damages that may be incurred except for these specified expense items will constitute an unfair situation. For example, it would not be fair to expect the package tour organizer to bear expenses such as air tickets purchased on behalf of the participant and cannot be returned. It is also clear that the organizer of the package tour will be deprived of the relevant earnings if the participant declines other participants, trusting that they will continue the contract. See Oktay (n 49) 221; Türky1lmaz (n 32) 103.

48 Sayın (n 32) 155.
} 
the rate stated in the contract (Directive art 16/3). As mentioned above, the law and PTSY clearly contradict at this point. Because while the law states that the refund must be made without any deduction; it is stated in PTSY that the consumer must suffer the necessary costs. According to principle of the hierarchy of norms, with those in the lower rungs of the hierarchy cannot be against to the norms in higher rungs ${ }^{49}$. A directive cannot burden the consumer unless there is a provision which makes it possible in the law. Therefore, the relevant article of PTSY is ineffective and must be ignored.

\section{In Case the COVID-19 Occurs After the Tour Starts}

Rights of consumers in case of breach of contract in the period after the tour started are regulated in a similar way to TKHK in PTSY. According to TKHK and PTSY, if it is clear that organizer fails or will fail to perform an important obligation, consumer has two alternative rights. In such a case, consumer is entitled to terminate the contract ${ }^{50}$ or maintain the contract by accepting the organizer's offer for an alternative arrangement ${ }^{51}$ (PTSY art 12/2\&3). The alternative arrangement offer must not incur additional costs to the consumer and organizer or its agent must compensate for the difference between the services offered to the consumer and the services stated in the contract ${ }^{52}$. One can argue that the second option is not consumer's best interest in respect of COVID-19 pandemic. Because most likely, maintaining the contract is not going to be possible due to pandemic precautions. In other deficiencies, which are relatively less important, consumer can ask for a reduction in the price (PTSY art 12/1).

When consumer chooses to terminate the contract, the package tour organizer or its agent can request an appropriate amount of the money from the consumer for the actions they have performed so $\operatorname{far}^{53}$ (TKHK art 51/7; PTSY art 12/3). On the other hand, organizer or its agent is obliged to provide free transfer to the place where the consumer starts the package tour or to another agreed place and to cover the expenses incurred in case of compulsory accommodation ${ }^{54}$ (PTSY art 12/4). The latest article is crucial especially for the consumers who are trapped in a different country or city other than the place of departure because of the pandemic. Owing to the article, they are not going to have to pay for their compulsory accommodation.

\footnotetext{
49 Paul Craig and Gráinne de Búrca, EU Law: Text, Cases and Materials (Oxford University Press 2015) 105.

so Termination here is ex nunc. Because in contracts of continuous performance, contract can be terminated only proactively if the performance started. See Baş Süzel (n 30) 254; Eren (n 41) 1002.

51 Baş Süzel (n 30) 254; Kadir Erk Pekmez, 'Tüketici Hukuku Çerçevesinde Paket Tur Sözleşmeleri' (Master Thesis, Akdeniz University Social Sciences Institute 2014) 93; Selin Sert, '6502 Sayılı Tüketicinin Korunması Hakkında Kanun Hükümlerine Göre Paket Tur Sözleşmeleri’ (2015) (22) TAAD Year 6 217, 235.

52 Sert (n 37) 235; Baş Süzel (n 30) 255.

53 Özel (n 28) 848; Baş Süzel (n 30) 255.

54 Sert (n 37) 236; Baş Süzel (n 30) 256.
} 
Another consequence of termination is the consumers' right to claim compensation for the damages incurred due to breach of contract according to general principles of the law of obligations ${ }^{55}$. However, when the failure results from force majeure or a situation that the organizer cannot foresee and prevent, consumer cannot claim compensation $^{56}$ (PTSY 14/1/c\&ç). Hence, if organizer of the package tour fails to perform an important obligation because of the COVID-19 and the tour is interrupted, the consumer can terminate the contract and claim refund for the services they could not benefit from; but cannot claim compensation, even if they suffer damages. This is because the COVID-19 prevents to establish a proper causal relation between the damage and the action.

\section{Legal Consequences}

When consumer terminates the contract, the contract is removed from the outset (ex tunc); the package tour organizer's or its agent's right to charge fees ends and the payments made are refunded to the consumer within fourteen days at the latest after the contract is terminated ${ }^{57}$ (PTSY art 10/4, 12/3, 16/5). Refunds are made according to articles of unjust enrichment (Turkish Code of Obligations art $77-82)^{58}$.

However, a recent regulation creates an exception to the refund deadline: "Provisional article - 1" of PTSY which took effect on 15 May 2020. According to the article, due to the COVID-19 pandemic, the price refunds for package tour contracts, which are envisaged to be performed as of 5 February 2020 and which include airline transport, are made within fourteen days following the sixth day after the flight ban is lifted. This means that the consumer who is already affected negatively by the pandemic, is going to have to wait for getting their money back; and what is worse, without knowing how long. Because if attention is paid, it can be seen that the refund deadline is not clear as it was before. The date of lifting of the flight bans is uncertain. This recent regulation is clearly against the interests of the consumer and it deserves every criticism. It does not comply with the main principle of the consumer law which is protecting the consumer. Besides, it is also against the principle of hierarchy of norms. Because it does not take place in the law and it takes a toll on consumers. Such an amendment cannot be made with a directive. It must be made with the law.

However, all criticism aside, there is one thing that might justify this regulation. If the article stayed the same, hundreds or thousands of travelers were going to apply for refund simultaneously. In this scenario, a lot of tour operators would probably

\footnotetext{
Sayın (n 32) 186; Mirhanoğulları (n 34) 44.

56 Özel (n 28) 268; Sayın (n 32) 186; Mirhanoğulları (n 34) 44.

57 Çabri (n 32) 853.

58 Hamamcioğlu (n 26) 292.
} 
bankrupt and none of the consumers could get their refund. It would possibly mean that causing consumers end up getting nothing, while actually trying to protect the consumer. Therefore, it can be argued that it is a regulation that made on economic grounds.

\section{Conclusion}

The termination of package tour contract is regulated similarly in EU and Turkish laws. However, this does not mean there are no differences. To sum up:

According to EU law (Directive 2015/2302 art 12/2) the "EU traveler" may terminate the package tour contract free of charge due to unavoidable and extraordinary circumstances, if there is a travel warning for the holiday destination. In case of termination the travel agency is obliged to refund the traveler all amounts already paid for the package without delay and in any event within 14 days (Directive 2015/2302 art 12/4).

According to Turkish law, when the COVID-19 emerged, consumer can terminate the contract regardless of how many days left to start of the package tour. If the tour is canceled before the starting date by the organizer because of the COVID-19, consumer can take the offer for an alternative tour or terminate the contract. If the tour had already started when the COVID-19 emerged, consumer, again, has the right to terminate the contract. As a consequence of the termination, refunds must be done within fourteen days following the sixth day after the flight ban is lifted (Directive provisional article-1). This extended refund deadline is only applied to terminations related to COVID-19 and include an air transportation.

Apart from the existing regulations, it can be quickly noticed that approaches of Europe and Turkey to the COVID-19 outbreak in respect of the package tour contracts are different. The recently added provisional article of PTSY which postpones the refund deadline until an indefinite date in Turkey is a proof of this difference. Because, in EU law, such a regulation did not take place. So, while EU travelers can get refunds within 14 days after termination; Turkish travelers are going to have to wait until an uncertain date to get refunds.

Peer-review: Externally peer-reviewed.

Conflict of Interest: The authors has no conflict of interest to declare.

Grant Support: The authors declared that this study has received no financial support.

Hakem Değerlendirmesi: Dış bağımsız.

Çıkar Çatışması: Yazarlar çıkar çatışması bildirmemiştir.

Finansal Destek: Yazarlar bu çalışma için finansal destek almadığını beyan etmiştir. 


\section{Bibliography}

Baş Süzel E, Tatil Sözleşmeleri (On İki Levha 2019)

Bergmann S and Blankenburg D, 'Unvermeidbare außergewöhnliche Umstände im Pauschalreiseund Luftverkehrsrecht' (2019) Neue Juristische Wochenschrift 3678-3683.

Çabri S, Tüketicinin Korunması Hakkında Kanun Şerhi (Adalet 2016).

Ceylan E, 'Paket Tur Sözleşmesiyle İlgili 6502 Sayılı Yeni Tüketicinin Korunması Hakkında Kanun 'a Göre Getirilen Düzenlemeler' (2015) 1 İstanbul Aydın Üniversitesi Hukuk Fakültesi Dergisi 71-98.

Ceylan U and Güven Ö Z, 'Yerli Turistlerin Satın Aldıkları Yurtdışı (Outgoing) Paket Turları Değerlendirmeleri Üzerine Bir Araştırma' (2017) 2 Bilecik Şeyh Edebali Üniversitesi Sosyal Bilimler Enstitüsü Dergisi 515-532.

Craig P and de Búrca G, EU Law: Text, Cases and Materials (Oxford University Press 2015).

Ecker M, 'Das neue Pauschalreisegesetz' (2017/2018) Jursitische Ausbildung und Praxis 238-242.

Eren F, Borçlar Hukuku Genel Hükümler (Yetkin 2014).

Führich E, 'Rücktritt vom Pauschalreisevertrag vor Reisebeginn wegen Covid-19-Pandemie' (2020) Neue Juristische Wochenschrift 2137-2141.

Führich E, 'Das neue Pauschalreiserecht' (2017) Neue Juristische Wochenschrift 2945-2950.

Führich E, 'Terror, Angst und höhere Gewalt - Antworten des Reiserechts' (2003) ReiseRecht atkuell 50-57.

Führich E, Basiswissen Reiserecht (4th edn, Vahlen 2018).

Hamamcıŏlu G, 'Paket Tur Sözleşmelerinde Tüketicinin Korunması' (2010) 68 İstanbul Üniversitesi Hukuk Fakültesi Mecmuas1 275-304.

Keiler S, ‘COVID-19: Gutscheinlösung für Reisende’ (2020) Recht der Wirtschaft 329-334.

Klafki A, Risiko und Recht (Mohr Siebeck 2017).

Löw S, 'Rechtsfolgen bei Änderung des Pauschalreisevertrags' (2020) Zeitschrift für Verbraucherrecht 133-138.

Löw S, 'Pauschalreiserecht in Zeiten der Covid-19-Pandemie' (2020) Neue Juristische Wochenschrift 1252-1255.

Löw S, 'Die Auswirkungen von Epidemien und Pandemien auf Pauschalreis- und Luftbeförderungsvertrag' (2020) Zeitschrift für Verkehrsrecht 156-161.

Mirhanoğulları Y E, '6502 Sayı1ı Tüketicinin Korunması Hakkında Kanuna Göre Paket Tur Sözleşmesinde Tüketicinin Korunması' (Master Thesis, İstanbul Aydın University Social Sciences Institute 2019).

Oktay S, Gezi Sözleşmeleri (Beta 1997).

Öksüz Ö, 'Tüketici Hukukunda Paket Tur Sözleşmeleri’ (2006) Türkiye Barolar Birliği Dergisi 331-351.

Özdemir G B, ‘Paket Tur Sözleşmesinde Taraflar ve Tarafların Borçları ve Hakları' (2011) Sosyal Bilimler Dergisi 68-74.

Özel Ç, Tüketicinin Korunması Hukuku (Seçkin 2019).

Pekmez K E, 'Tüketici Hukuku Çerçevesinde Paket Tur Sözleşmeleri' (Master Thesis, Akdeniz University Social Sciences Institute 2014).

Savaş S, 'Paket Tur Sözleşmeleri' (Master Thesis, Atatürk University Social Sciences Institute 2019). 
Sayın F E, 'Paket Tur Sözleşmesinde Tüketicinin Korunması' (Master Thesis, İstanbul University Social Sciences Institute 2013).

Sert S, '6502 Sayılı Tüketicinin Korunması Hakkında Kanun Hükümlerine Göre Paket Tur Sözleşmeleri’ (2015) TAAD Year 6 217-240.

Sheldon PJ and Mak J, 'The demand for package tours: A mode choice model' (1987) 25 Journal of travel research 13-17.

Steinrötter B, jurisPraxisKommentar-BGB $\S 651$ h (juris 2020).

Teichmann A, Bürgerliches Gesetzubuch § 651j (17th edn, CH Beck 2018).

Tonner K, ‘Auswirkungen von Krieg, Epidemie und Naturkatastrophe auf den Reisevertrag' (2003) Neue Juristische Wochenschrift 2783-2787.

Türkyılmaz E, 'Paket Tur Sözleşmeleri’ (Master Thesis, Kadir Has University Social Sciences Institute 2017). 
